\title{
Faceless and Forgotten Victims
}

\section{Besim Kusari}

PhD Candidate at Tirana European University, Albania.

Email: besimkusari@gmail.com

\section{Benina Rizvanolli-Kusari}

Ma.Sc. International Law.

Email: benina.kusari@gmail.com

Eliza Thana

BA of Psychology.

Email: thanaee@state.gov

Doi:10.5901/mjss.2013.v4n10p234

\begin{abstract}
The effect of wars on direct or indirect victims varies depending on the type of crime committed against them. The wars in former Yugoslavia have left a tremendous number of people with long term trauma. While a large number of people once the war is over, start rebuilding their lives trying to leave the past behind, that does not happen with victims of rape and missing persons. But then again you expect that the state is the one that will help these victims lead their way towards a better life that does not happen either. The first category is stigmatized for life by their families and the society in general. The second category is neglected and forgotten by the state just like those people never existed. These are the two categories which are forgotten by their own society and as such are often forgotten by the International Community too. Fourteen years have passed since the war in Kosovo and these two categories remain faceless and forgotten; the first ones without a shoulder to cry on and the second ones without a grave to rest in peace. Kosovo has an obligation to recognize and support the 'Faceless' and the 'Forgotten'.
\end{abstract}

Keywords. Crimes against humanity, human rights, victims, state obligation, armed conflict.

\section{A short history of Kosovo}

Kosovo was part of Yugoslavia until the breakup in 1990 when Slovenia was the first Yugoslav republic to declare independence. This was accomplished with virtually no military action. Croatia and Bosnia on the other hand went through war which at the end resulted in the independence of these republics as well. Once these wars ended, the conflict started focusing more in Kosovo.

The process to abolish Kosovo autonomy from 19741, began in March 1989, under the leadership of Slobodan Milloshevic ${ }^{2}$. The Constitution of Serbia was amended to redefine Kosovo as a region in Serbia, with administrative and executive control by the Serbian National Assembly. The expelling of the workers from factories, students from schools and basically with no Albanians as part of any government institutions, increased the dissatisfaction of the Albanians with the situation in Kosovo.

Civil disturbances in Kosovo began by 1990 and they resulted in violence. Hundreds of people were injured and many killed by the security forces. For Serbia, the Albanians posed a 'huge threat' specifically due to their desire for independence from Serbia. Along with the non-violent solution to the crisis under the leadership of Ibrahim Rugova ${ }^{3}$, the

1 In 1974 Kosovo had its highest level of autonomy, within Yugoslavia, since the end of world War II. Kosovo was not part of Serbia. This is the reason why Serbia was against this Constitution.

${ }^{2}$ Slobodan Milosevic was elected President of Serbia in 1989. He was involved in the Kosovo crisis and NATO confrontation. He lost power in 2000 and was charged by ICTY with crimes against humanity. Milosevic died in prison on March 11, 2006.

$3 \mathrm{Ibrahim}$ Rugova was elected the first President of Kosovo in 2002. He remained in this position until 2006, when he died from lung cancer. 
leader of the Democratic League of Kosovo, groups of Albanians started to mobilize in groups called Kosovo Liberation Army (KLA) as response to the Serb repression against the Albanians. The open hostilities between the KLA and the Serb forces began in 1998 and they concentrated mainly in rural area. In its Decision No. 259 of 15 October 1998 the OSCE Permanent Council, acting within the framework of the United Nations Security Council Resolution No. 1199, declared the preparedness of the OSCE to embark upon verification activities related to compliance of all parties in Kosovo with the requirements set forth by the international community with regard to the solution of the crisis in Kosovo. The mission was called the OSCE Kosovo Verification Mission (KVM).

\section{NATO Airstrikes against Serbia}

Despite the presence of the OSCE monitors, the concentration of Serb forces continuously increased. There were continuous conflicts between the KLA and Serb Forces concentrating mainly on the rural areas. In February 1999 in the village of Reçak, Kosovo Serb forces massacred 45 Albanian civilians. The victims were ages from 12 to 99 years old. The head of OSCE KVM William Walker after visiting Reçak stated that, the deaths were a 'massacre' by Serb police. The head of a Finnish investigating team assigned to investigate the killings in Recak called the January massacre of 45 ethnic Albanian civilians in Recak 'a crime against humanity'(The Guardian, 1999). This massacre led to massive international pressure on Serbia to stop their ethnically motivated killings of Albanians, but Serbia continued to deny the massacres. The Reçak massacre and the determination of the experts that the killings in Reçak represented ethnic cleansing was the final decision that triggered NATO airstrikes against Serbia ${ }^{4}$.

Due to the deterioration of the security situation in Kosovo, on 20 March 1999, the Chairman-in-Office of the OSCE made the decision to withdraw the KVM for safety reasons, and perhaps as another means of putting pressure on Yugoslav authorities, who were being threatened with air strikes (Maisonneuve, 2000). With the evacuation of the OSCE staff, the attacks against Kosovo Albanians intensified. After the final attempts for peace negotiations, NATO airstrikes remained as the only option to end violence in Kosovo. The airstrikes commenced on $24^{\text {th }}$ March initially targeting Serb forces in Kosovo, to expand later with targets in Serbia as well. Using the pretext of the NATO bombing, the government intensified its offensive against the KLA and ordered the expulsion of more than 850,000 Kosovar Albanians (HRW, 2001). Refugees fled to Albania, Macedonia, Montenegro and they had their documents confiscated the license plates removed at the border ${ }^{5}$. Thousands of refugees were placed in other countries such as Germany, France, Norway, Sweden, Turkey, UK, Poland, Spain, Portugal, Switzerland, Italy, Israel etc(IOM 1999).

The NATO airstrikes lasted for 78 days and came to an end after the signing of the Military Technical Agreement with Serbia on 10th June 1999.

\section{The type of victimization from the $1998-1999$ conflict}

The Serb forces in Kosovo were comprised of various structures: military, local police, police deployed from Serbia, reservists, various paramilitary groups. This mixed structure contributed to massive victimization throughout Kosovo taking different forms. Massive killings, massacres of Albanian of all ages starting from babies to the most elderly became common especially throughout the NATO airstrikes. With no way how to counter fight NATO, Serbs continued with their campaign in particular against the innocent civilian population and massive destruction of properties.

The types of crimes committed during the 1998-1999 period in Kosovo included (HRW,2001):

- Group killings;

- Massacres;

- Rapes;

- Arbitrary Arrests, Detentions and Compulsory Labor;

- Internal displacement of civilians and Expulsion of civilians to neighboring countries;

- Destruction of Civilian Property and Mosques;

- Contamination of Water Wells;

- Robbery and Extortion;

\footnotetext{
${ }^{4}$ Kusari, Benina - the co-author of this publication worked with OSCE KVM in Gjakova, Kosovo during the period from January 1999 until the OSCE evacuation in March 1999, and as such in many occasions had to deal with cases of civilians who were mistreated and killed by the Serb forces during this period in Gjakova area.

5 This so-called 'identity cleansing' documented by Human Rights Watch and other organizations gathering testimony in Albania strongly suggests an attempt by Belgrade to strip Kosovo Albanians of their citizenship and to frustrate future efforts to return home".
} 
- Torture;

- $\quad$ Use of Human Shields;

- Placement of Landmines;

Even now, 14 years after the war, not all the victims have been accounted for. A major reason for this is the deliberate actions of the Serb forces to destroy the evidence of their crimes by removing bodies of the persons killed. A top Serbian Ministry of Internal Affairs official announced on May 25 that Milosevic had ordered then-Interior Minister Vlajko Stojiljkovic to eliminate "all traces which could lead to any evidence of crimes" in Kosovo (HRW,2001). Additionally, a number of persons abducted during the war are still missing and it is estimated that there is a large number of victims of rape who are reluctant to come out in open and report crimes committed against them.

The first official numbers on the consequences of the 1998-99 conflict in Kosovo were published in May 2013 by the State Archive Academy of Kosovo. According to the publications for the period January 1998-12 June 1999, 11.840 persons were killed. From these numbers 1.392 were children up to the age of 18 years, 296 children aged up to 5 years, 1.739 females, and 1.882 elderly over 65 years. A number of 1450 persons are still missing and it is estimated that approximately 20.400 Albanian women were raped (SAAK, 2013).

When discussing the victimization in Kosovo during 1998-99, it is not sufficient to only focus on the statistical aspect of the victimization but more importantly on the impact of these crimes on the victims, their families and the society in general and how much, or better to say how little, was done for these victims in helping to alleviate this pain.

\section{Criminal responsibility for the crimes}

The wars in the Ballkans have clearly proven that the likelihood that states will breach the principles of Humanitarian Law during armed conflicts is major. This happens during the conflicts of International or even Non-international nature. According to the report published in October 2011 by the International Committee of the Red Cross it was concluded that ". . . the international humanitarian law continues to provide an appropriate framework for regulating the conduct of parties engaged in armed conflicts. . . In most cases what is required to improve the situation of victims of armed conflicts is stricter compliance with the existing legal framework, rather than the adoption of new rules" (ICRC, 2013).

There is no doubt at this point that the existing rules are sufficient, but the problem is that at the end of conflicts the individuals or the governments try to hide behind the various interpretations of such rules and as such avoid the responsibility for the crimes committed.

\subsection{Group vs individual responsibility}

The issue of the state responsibility for crimes of international and non-international crimes is best described on the International Law Commission Draft articles on responsibility of States for Internationally Wrongful Acts (ILC, 2001). What is important at this point to mention from this report is the definition given in Article 2, which states that an internationally wrongful act can consist of "an act or omission". When referring only to this article then it is very difficult to believe or to say better, very unlikely that senior officers of Serbian and Yugoslav forces were unaware of the crimes occurring in Kosovo. Although there was a large number of various paramilitary groups in Kosovo, as witnessed by many victims and witnesses the crimes occurred frequently in the presence, and with the acquiescence, of military officers. Additionally, a large number of documents found after the war clearly show that the crimes committed in Kosovo were committed 'under orders'. These documents in plain paper describe in detail how many persons were killed in different areas, how many of them are males and females, where were they buried etc. This is a clear indicator that crimes were not committed only randomly and without any planning. These lists later served to exhume the bodies in organized ways which were then buried in massive graves in Kosovo and Serbia. Some allegations say also a large number of the bodies were burned (HRW, 2001). Isn't this a clear indication that senior officers in Serbia have known about these crimes? Yet, instead of apprehending or punishing those responsible for the crimes, many of the senior military and police officers who were active during the war in Kosovo got promoted after the war (HRW, 2001).

Although the number of victims in Kosovo was huge, the International Criminal Tribunal for the Former Yugoslavia (ICTY) has only been investigating the involvement of the senior officers and commanders in these crimes. In the overall picture this is not sufficient for the victims of such crimes. It is not sufficient for the sole fact that they want justice for the crimes committed against them. A report published by the Council for the Protection of Human Rights and Freedom in Kosovo, says that more than 1426 persons have been reported to have been directly or indirectly involved in the crimes 
in Kosovo ${ }^{6}$. The names of the criminals in these lists have been identified by survivors and family members of victims. Although, there are many eyewitnesses and a large number of cases are waiting to be resolved, the answer to the plight of those victims is that these criminals are not reachable for the local authorities and EULEX ${ }^{7}$ mission operating in Kosovo, because they are not physically in Kosovo (Borchardt, 2013).

\section{State obligation for rehabilitation of the victims}

Depending on the scale of victimization, the attention, the support and the needs of the victims of crime varies. But, why no one takes responsibility for these victims? While Serbia continues to deny the crimes committed, Kosovo Government on the other side is not fulfilling its part of the obligation towards these victims. This failure refers to many aspects such as:

- Improper treatment of the different categories of victims in the domestic legislation;

- Pending charges against identified criminals who committed these crimes;

- Lack of compensation scheme for victims and their families;

- Lack of rehabilitation programs for victims of certain categories, etc.

Unfortunately, even 14 years after, most of the rehabilitation programs are run by nongovernmental sector, and with the assistance of the international donors and with limited support by the government. Most of the attention of the Government of Kosovo was focused on the Declaration of Independence ${ }^{8}$, the EU integration and stabilization of the relationship with Serbia, leaving behind the needs of the numerous victims of war. Although, these crimes were committed by Serbia, it does not justify the insufficient support offered to the victims and their families by the Government of Kosovo.

\subsection{Treatment of the victims of sexual violence in Kosovo}

As seen from the above numbers it is clear that just like in Bosnia, rape was used as tactic of war in Kosovo as well. In a male dominated area like Kosovo, it was clear rape is one way not only to inhumanly treat the victim but it also serves as a way to destroy families and communities; and instill fear in the general population. This effect of rape has been recognized also by the UN Resolution 1820 which noted that "women and girls are particularly targeted by the use of sexual violence, including as a tactic of war to humiliate, dominate, instill fear in, disperse and/or forcibly relocate civilian members of a community or ethnic group."

Women are most targeted as victims of these crimes, crimes which in small communities like Kosovo are considered crimes of dishonesty for the victim. The effects of such crimes are enormous. A victim of such crime is stigmatized for life by their own family, relatives and by many people in the society. This is the fate of the victims of rape in Kosovo.

Rapes of women in Kosovo occurred in various methods such as: individual raping in homes, group raping in rape camps or rape in public while victims were trying to flee the country in convoys in which case many of them ended up being raped right in front of the eyes of the other people in the convoys and some of the victims were killed after being raped (HRW, 2000). For those who were not raped in public they remained "faceless" as they decided to never tell their stories in public. Despite the huge psychological trauma they have suffered they remain silent and hidden for the only purpose of not "shaming the family". It is this category which whenever they tell their stories on the media their faces are distorted so they would not be recognized by their own society. Some of them even hide from their own families and relatives who even to this day are not aware that they were raped. Those women need support and assistance to overcome their trauma.

\footnotetext{
${ }^{6}$ Report lists the names of criminals and the area in which they are suspected for committing crimes.

${ }^{7}$ European Rule of Law Mission in Kosovo. EULEX works within the framework of UN Security Council Resolution 1244. EULEX mandate is to investigate, prosecute and adjudicate sensitive cases using its executive powers; and monitor, mentor, and advise local counterparts in the police, justice and customs fields.

${ }^{8}$ Kosovo declared its Independence on 17th February 2008.
} 


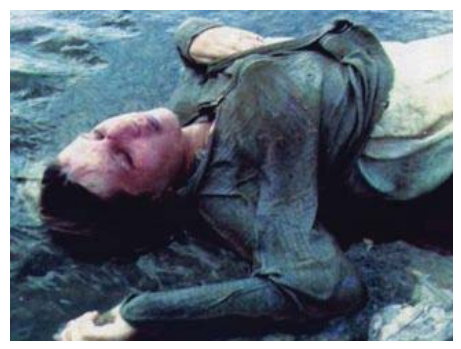

Fig.2. An Albanian girl raped and killed, found in Prizren area, Kosovo (Photo taken from Pashtriku.beepworld.de)

Another absurdity of the society was the difficulties faced by the victims of rape during the war who have testified before the ICTY on their terrible experiences, especially women coming from rural areas. As if this was not enough trauma for them, when they came back to their own country and although they had testified as anonymous witness, they had to face the insults of individuals who thought that they should have never gone to testify ${ }^{9}$. If these and other victims do not tell their stories, who will tell the story on their behalf? Who can better describe the horror they faced, a horror which is so fresh even 14 years after?

Stories of women raped have been collected throughout Kosovo. A gynecologist from NGO "Life in Kastriot" who treated thousands of victims of rape during the war ages 12-45 years old has collected and published 857 stories told by women who were raped (Selimi, 2003). Although, their names remain anonymous, this is the way how they have chosen to secretly tell their lifelong nightmares. Although 'faceless' and 'shamed for life' these victims try to educate the society that such a crime should not be hidden and that they have had to bare the biggest burden for the entire society.

The irony of all this is that for 14 years these victims have remained 'faceless' and 'hidden' in silence. So 14 years after the war these victims are still waiting for justice to prevail, are still waiting for the society to give them a respectful place in the society as the true heroes who have sacrificed so much for this country. One of the women raped during the war during an interview said, "I have waited that our state will do something to relieve our condition, to rehabilitate us, to bring us back to life. In our country if you have a bullet wound you are considered a hero and you are proud, but if you were raped it is a humiliation and you should keep your head down" (Koha net, 2012).

The majority of the assistance offered to these women is dependent on the good will of the various nongovernmental organizations and the international donors. It wasn't until March 2013 when the first initiative to provide government support to these victims took place at the Kosovo Parliament. It was the initiative to include this category of victims in the legislation which offered financial support to war veterans and civilian victims of war ${ }^{10}$. Surprisingly enough this initiative was not supported by all the groups in the society (WRI, 2013). Various comments on how this subject should not be brought up as a matter for discussion since it is a shame, has pushed many organizations and victims to react and demand that they should be treated with respect and compassion as they deserve and not bare all their life the "seal of rape". Finally, the government has started to look at these victims from a different perspective and to do something more for them to recognize their pain and try at least a little bit alleviate their pain.

\subsection{Missing persons in Kosovo and the treatment of their families}

Massive killings and massacres; and abduction of civilians were another category of crimes committed in Kosovo. It is estimated that more than 4000 persons were abducted during the war and a large number of them were found dead and buried in massive graves in Kosovo and Serbia. Yet, more than 1400 yet remain unaccounted for. "The families of the missing persons have to live with the never-ending pain of not knowing what happened to their missing loved ones. They have had to bear this burden for over a decade. The authorities in both Belgrade and Pristina have the primary responsibility to provide answers and support to the families. There is a pressing need for both sides to step up their efforts and use every available resource to quickly obtain more information." (Milner, 2011).

\footnotetext{
${ }_{9}$ Statement during the Conference on Roundtable discussion marking the day for the Elimination of Violence against Women, organized by the British Embassy, 25th November 2012 in Pristina, Kosovo.

${ }^{10}$ The draft amendments to the Law on the Status and Rights of Martyrs, Invalids, Veterans, Members of Kosovo Liberation Army, Civilian Victims, and their Families would give legal recognition, respect and public acknowledgement to persons who suffered sexual violence.
} 
The absence of the remains of the missing persons deprives the families of the missing persons but also deprives wider society from the only physical symbol to remembering their beloved ones. Authorities have often chosen to remain silent on this issue like these people never existed. It is the effort and the persistence of the families of the 'forgotten' victims that continue to remind the authorities that this issue should be a top priority on the political agenda for regional cooperation by demanding clarifications on the whereabouts of the remains, so that victims could finally rest in peace.

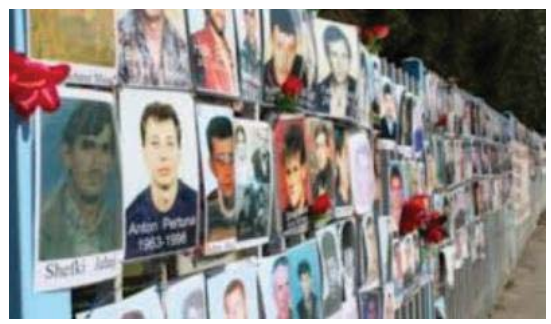

Fig.3. Photos of missing persons hanging on the fence of the Parliament building in Pristina, Kosovo (Photo taken from www.Koha.net)

According to the United Nations Basic Principles and Guidelines on the Right to a Remedy and Reparation for Victims of Gross Violations of IHL, "Satisfaction should include, where applicable, ...The search for the whereabouts of the disappeared, for the identities of the children abducted, and for the bodies of those killed, and assistance in the recovery, identification and reburial of the bodies in accordance with the expressed or presumed wish of the victims, or the cultural practices of the families and communities(UN AG, 2006);

With the purpose of having a name-by-name record of all victims, both killed and missing in Kosovo in the period 1998- 2000, Humanitarian Law Center ${ }^{11}$ have taken an initiative to collect names and stories for all these cases. The aim of this project titled 'Kosovo Memory Book' was initiated with the purpose to improve compliance with Human Rights obligations and accountability of duty holders by creating the conditions (a register of victims) for state-sponsored truthtelling processes and reparations programmes (HLC, 2011).

\section{Reparation for victims - whose responsibility is that?}

The United Nations Basic Principles and Guidelines on the Right to a Remedy and Reparation for Victims of Gross Violations of IHL stipulates that "In accordance with domestic law and international law, and taking account of individual circumstances, victims of gross violations of international human rights law and serious violations of international humanitarian law should, as appropriate and proportional to the gravity of the violation and the circumstances of each case, be provided with full and effective reparation, ... which include the following forms: restitution, compensation, rehabilitation, satisfaction and guarantees of non-repetition.

The sole fact that at least the above categories are not treated by their own society with respect, compassion and dignity, leaves little room to even discuss about the possibility of a modicum of reparation for these victims and their families. The Government of Kosovo should not use as an excuse that the reparation for these victims should come from Serbia and not from Kosovo. The Government should do their part by offering continuous support and assistance to these victims. Additionally, the Government should work harder in pushing forward the agenda of determining the criminal responsibility of those criminals and their superiors, if not possible through domestic courts then it should give its contribution to assist the International Criminal Justice to prosecute these criminals.

\section{Conclusion}

Every person deserves to live free of any pressure and violence by others. The crimes against humanity committed in Kosovo have left open wounds for many people. Rehabilitation of victims is an extremely difficult, long and challenging

11 "HLC" -The Humanitarian Law Center in Kosovo was established in Prishtinë in May 1997, by a well known human rights activist Mrs. Nataša Kandić, as a branch office of the Humanitarian Law Center. 
process even for therapists who treated these victims over the years in particular if he or she has directly or indirectly been affected by the conflict.

Victims of sexual violence need lifelong support not only from their families, but more from the society and their own government. They need to be recognized and supported to the maximum and at minimum they need a public apology for the crimes committed against them.

Missing persons are the 'silent' victims of war. They have no voice but others should speak on their behalf. Their families should not be kept for decades under the anguish of whether they will ever bury their beloved ones, whether they will ever have a grave to cry for them. This never-ending pain has to stop.

The Government of Kosovo, the Government of Serbia and International Community should not remain silent on the crimes committed in Kosovo. Those crimes happened in the heart of Europe, where the rights and liberties of people are considered the core principles of a democratic society. People in Kosovo have been denied those rights and those responsible should be held accountable. Those victims should no longer be 'faceless and forgotten'.

"It is a kingly act to assist the fallen."

- Mother Theresa -

\section{References}

Borchardt, Bernd, (2003), EULEX Head of Mission, EULEX and War Crimes. (Online) Available: http://www.eulex-kosovo.eu/ en/news/000427.php.

Clark, Howard, (2013), WRI condemns 'shameful' attacks on Nazlie Bala in Kosovo, London.

Human Rights Watch Report, (2001), Under Orders, War Crimes in Kosovo, United States of America.

Human Rights Watch, (2000), Serb Gang-Rapes in Kosovo Exposed, (Online) Available: http://www.hrw.org/news/2000/03/20/serbgang-rapes-kosovo-exposed.

International Committee of the Red Cross,(2011), 31st International Conference of the Red Cross and the Red Crescent, Strengthening legal protection for victims of armed conflicts, Geneva, Switzerland, pg.4.

International Law Commission, (2001), Responsibility of States for Internationally Wrongful Acts.

International Organization for Migration, (1999) humanitarian evacuation statistics. (Onile Available: http://www.ess.uwe.ac.uk/Kosovo/ Kosovo-Refugees 77 .html.

Koha.Net, Femrat e dhunuara në luftë, të keqtrajtuara në paqe, [Women raped in war, mistreated in peace] Published on 09.04.2012 22:15. (Online) Available: http://www.koha.net/?page=1,13,94953.

Maisonneuve, Michel J.R., (2000), The Kosovo Verification Mission, Canadian Military Journal, §52.

Milner, Lina, (2011), Proceedings from 10th public session of the working group, Belgrade. Meeting chaired by the International Committee of the Red Cross (ICRC).

Resolution 1820 (2008), adopted by the Security Council at its 5916th meeting.

Selimi, Luljeta, (2003), 'Rrefimet e femrave të dhunuara gjatë luftës në Kosovë [Stories of women raped during the war in Kosovo], Prishtinë.

The Guardian, (1999), Recak report finds Serbs guilty, (Online) Available: http://www.guardian.co.uk/world/1999/mar/18/4.

The Humanitarian Law Center in Kosovo (2011) The Kosovo Memory Book: 1998-2000, Prishtinë. (Online) Available: http://www.kosovomemorybook.org

The State Archive Academy of Kosovo (2013), "Crimes of Serbia against children in Kosovo 1998-1999", Prishtina.

The State Archive Academy of Kosovo", (2013),"Crimes of Serbia in Kosovo 1998-1999" Prishtina.

United Nations General Assembly, (2006), Basic Principles and Guidelines on the Right to a Remedy and Reparation for Victims of Gross Violations of International Human Rights Law and Serious Violations of International Humanitarian Law, A/RES/60/147. 